\title{
Clinical significance of white bile in the biliary tree
}

\author{
R. G. ELMSLIE, M. E. C. THORPE, J. V. L. COLMAN, \\ C. R. BOUGHTON, G. R. PRITCHARD, AND R. J. HOY \\ From the Departments of Surgery and Medicine, The Prince Henry Hospital, Sydney, Australia
}

'White bile' is a clear, colourless, watery fluid found occasionally in the biliary tree proximal to an extrahepatic biliary obstruction. Thus it is neither white nor bilious; and it is not viscid and opaque like the fluid found in the obstructed gall bladder.

With the exception of the paper by Judd and Lyons (1923) previous reports on white bile dealt either with a single patient (Edington and McCallum, 1930; Lake, 1934; Flint, 1937; Griffiths, Haber, Rees, and Smith, 1963; Bouchier and Cooperband, 1965), or with several patients (Aronsohn, 1936; Hawthorne and Sterling, 1955), or with experiments carried out in animals (Rous and McMaster, 1921; McMaster, Broun, and Rous, 1923; Cameron and Oakley, 1932; Aronsohn, 1935; Haber and Rees, 1963). These reports contain certain generalizations about the possible clinical significance of white bile. It could be assumed that it is found most frequently in those obstructions due to stone (Flint, 1937; Hawthorne and Sterling, 1955) or either stone or stricture (Judd and Lyons, 1923); that it will be found only when the gall bladder is either distal to the obstruction or when it is not functioning (Rous and McMaster, 1921; McMaster et al, 1923; Judd and Lyons, 1923; Lake, 1934; Griffith et al, 1963); that it occurs only when there is infection in the fluid (Aronsohn, 1935 and 1936); that total obstruction is always present (Aronsohn, 1936); and that it signifies severe liver damage and a grave immediate prognosis (Flint, 1937). In this paper we report the findings in nine patients admitted to Prince Henry Hospital each with obstructive jaundice and each with clear, colourless, watery fluid in the biliary tree. The findings in these patients have been examined to appraise the clinical significance of finding white bile at operation.

\section{METHODS}

Since 1965 we have treated nine patients who hao white bile in the major bile ducts (Table I), In seven patients the specimen was collected from a major hepatic duct by aspiration of the catheter inserted into the liver at preoperative percutaneous transhepatic cholangiography before injecting the radioopaque dye. In two patients, the fluid was obtained during the early phase of operation, on one occasion (case 8) from the common bile duct and in another (case 5) from the gall bladder which communicated normally with the biliary tree. Five specimens were Gram stained and cultured by plating out on blood agar plates and incubating under aerobic and anaerobic conditions. Each specimen of white bile was examined for bilirubin (Malloy and Evelyn, 1937), bile salts (Varley, 1962), alkaline phosphatase (AutoAnalyzer, Technicon Corporation, method N-6P), and cholesterol (Abell, Levy, Brodie, and Kendall, 1952). Sodium, potassium, and chloride (AutoAnalyzer, Technicon Corporation, method $\mathrm{N}$-219) were estimated in each specimen of white bile except that obtained from case 9 .

The serum bilirubin (Malloy and Evelyn, 1937) level was estimated before operation (usually on the day preceding operation, and always within four days of operation) and at irregular intervals (usually every four to five days) after operation.

\section{RESULTS}

The results of the biochemical examination of white bile are recorded in Table II. Certain clinical features were common to the nine patients in this study (Table I). All were over 40 years of age, all had been jaundiced for some time and all survived an operation to relieve biliary obstruction. In six of the seven patients submitted to percutaneous transhepatic cholangiography the obstruction was judged to be radiologically complete. In the other patient (case 4) the dye appeared in the duodenum after one and a half hours (Fig. 1). In seven patients the obstruction was a malignant tumour, in one patient it was probably a cancer of the head of the pancreas (although a stone was also found in the common duct), and in the remaining patient it was a stone impacted at the lower end of the common duct (Table I).

In two instances (cases 1 and 7) the site of the obstruction was proximal to the entry of the cystic duct into the biliary tree. In six patients (cases 2, 3, 4, 5,6 , and 8 ) the site of the obstruction was distal to the entry of the cystic duct into the biliary tree and in four of these (cases 2, 4, 5, and 6) the gall bladder, although it shared in the biliary distension, was not 
TABLE I

CLINICAL DETAILS OF PATIENTS WITH WHITE BILE

\begin{tabular}{|c|c|c|c|c|c|c|c|}
\hline $\begin{array}{l}\text { Case } \\
\text { No. }\end{array}$ & Age & $\operatorname{Sex}$ & Diagnosis & $\begin{array}{l}\text { Site of } \\
\text { Obstruction }\end{array}$ & $\begin{array}{l}\text { State of } \\
\text { Gall Bladder }\end{array}$ & Operation & Outcome \\
\hline 1 & 56 & $\mathbf{M}$ & Cancer of gall bladder & $\begin{array}{l}\text { Common hepatic } \\
\text { duct }\end{array}$ & $\begin{array}{l}\text { Infiltrated with } \\
\text { cancer }\end{array}$ & Hepaticojejunostomy & Died $3 / 12^{3}$ \\
\hline 2 & 47 & $\mathbf{M}$ & Cancer of pancreas & Common bile duct & $\begin{array}{l}\text { Distended; } \\
\text { apparently } \\
\text { normal }^{2}\end{array}$ & $\begin{array}{l}\text { Cholecystjejunostomy, } \\
\text { enteroanastomosis }\end{array}$ & Died 8/12 \\
\hline 3 & 67 & $\mathbf{M}$ & $\begin{array}{l}\text { Impacted stone in } \\
\text { common bile duct }\end{array}$ & $\begin{array}{l}\text { Distal common bile } \\
\text { duct }\end{array}$ & $\begin{array}{l}\text { Distended; } \\
\text { chronic } \\
\text { cholecystitis }\end{array}$ & $\begin{array}{l}\text { Cholecystectomy, } \\
\text { choledocholithotomy } \\
\text { sphincterotomy, } \\
\text { choledochoduodenostomy }\end{array}$ & $\begin{array}{l}\text { Alive and well } \\
16 / 12\end{array}$ \\
\hline 4 & 41 & $\mathrm{~F}$ & Periampullary cancer & $\begin{array}{l}\text { Distal common } \\
\text { bile duct }\end{array}$ & $\begin{array}{l}\text { Distended; } \\
\text { cellular } \\
\text { infiltration }\end{array}$ & $\begin{array}{l}\text { Pancreaticoduoden- } \\
\text { ectomy }\end{array}$ & Died $9 / 12$ \\
\hline 5 & 69 & $\mathbf{M}$ & Cancer of pancreas & Common bile duct & $\begin{array}{l}\text { Distended; } \\
\text { apparently } \\
\text { normal }^{2}\end{array}$ & $\begin{array}{l}\text { Cholecystenterostomy } \\
\text { with Roux-Y loop }\end{array}$ & Died 5/12 \\
\hline 6 & 77 & $\mathbf{F}$ & Periampullary cancer & $\begin{array}{l}\text { Distal common bile } \\
\text { duct }\end{array}$ & $\begin{array}{l}\text { Distended; } \\
\text { apparently } \\
\text { normal }^{2}\end{array}$ & $\begin{array}{l}\text { Cholecystjejunostomy } \\
\text { with Roux-Y loop }\end{array}$ & Died $5 / 12$ \\
\hline 7 & 43 & $\mathbf{F}$ & $\begin{array}{l}\text { Cancer of common } \\
\text { hepatic duct }\end{array}$ & $\begin{array}{l}\text { Common hepatic } \\
\text { duct }\end{array}$ & $\begin{array}{l}\text { Collapsed; } \\
\text { apparently } \\
\text { normal }^{2}\end{array}$ & $\begin{array}{l}\text { Insertion of trans- } \\
\text { hepatic tube }\end{array}$ & Died 10/52 \\
\hline 8 & 68 & $\mathbf{M}$ & Cancer of pancreas ${ }^{1}$ & Common bile duct & $\begin{array}{l}\text { Small; packed } \\
\text { with stones }\end{array}$ & $\begin{array}{l}\text { Cholecystectomy, } \\
\text { choledocholithotomy, } \\
\text { choledochoduodenostomy }\end{array}$ & $\begin{array}{l}\text { Survived } \\
5 / 52\end{array}$ \\
\hline 9 & 53 & $\mathbf{M}$ & Cancer of pancreas & Common bile duct & $\begin{array}{l}\text { Distended; } \\
\text { apparently } \\
\text { normal }^{2}\end{array}$ & $\begin{array}{l}\text { Hepaticojejunostomy, } \\
\text { enteroanastomosis, } \\
\text { cholecystostomy }\end{array}$ & Died 18/52 \\
\hline
\end{tabular}

${ }^{1}$ Diagnosis not proven.

${ }^{2}$ Gall bladder not examined histologically.

${ }^{3} \mathrm{~A}$ necropsy was performed on all patients who died.

${ }^{4}$ Lost to follow up.

TABLE II

RESULTS OF INVESTIGATIONS ON WHITE BILE

\begin{tabular}{|c|c|c|c|c|c|c|c|}
\hline $\begin{array}{l}\text { Case } \\
\text { No. }\end{array}$ & Source & $\begin{array}{l}\text { Alkali } \\
\text { (King. }\end{array}$ & $\begin{array}{l}\text { Phosphatase } \\
\text { rmstrong units) }\end{array}$ & $\begin{array}{l}\text { Cholesterol } \\
(m g \%)\end{array}$ & $\begin{array}{l}\mathrm{Na} \\
(\mathrm{m} \text {-equiv } \mid l)\end{array}$ & $\begin{array}{l}K \\
(m \text {-equiv } / l)\end{array}$ & $\begin{array}{l}\mathrm{Cl} \\
(\mathrm{m} \text {-equiv } / l)\end{array}$ \\
\hline 1 & $\begin{array}{l}\text { Percutaneous transhepatic } \\
\text { cholangiography }\end{array}$ & Sterile & $1 \cdot 2$ & Nil & 138 & 3.6 & 152 \\
\hline 2 & $\begin{array}{l}\text { Percutaneous transhepatic } \\
\text { cholangiography }\end{array}$ & Sterile & 0.8 & Nil & 138 & $4 \cdot 3$ & 131 \\
\hline 3 & $\begin{array}{l}\text { Percutaneous transhepatic } \\
\text { cholangiography }\end{array}$ & - & Nil & Nil & 137 & 3.9 & 130 \\
\hline 4 & $\begin{array}{l}\text { Percutaneous transhepatic } \\
\text { cholangiography }\end{array}$ & Enterobacteriaceae & Nil & Nil & 118 & $3 \cdot 4$ & 99 \\
\hline 5 & Gall bladder ${ }^{1}$ & Sterile & Nil & Nil & 132 & $4 \cdot 1$ & 140 \\
\hline 6 & $\begin{array}{l}\text { Percutaneous transhepatic } \\
\text { cholangiography }\end{array}$ & Sterile & $1 \cdot 3$ & 26 & 141 & $3 \cdot 8$ & 107 \\
\hline 7 & $\begin{array}{l}\text { Percutaneous transhepatic } \\
\text { cholangiography }\end{array}$ & - & $2 \cdot 2$ & Nil & 139 & $4 \cdot 0$ & 145 \\
\hline 8 & Common bile duct & - & Nil & Nil & 136 & $2 \cdot 3$ & 136 \\
\hline 9 & Percutaneous transhepatic & - & Nil & Nil & Not done & Not done & Not done \\
\hline
\end{tabular}

${ }^{1}$ This patient had free communication between the gall bladder and the biliary tree proximal to the obstructing cancer of the pancreas.

grossly abnormal. In the final patient (case 9) a carcinoma of the pancreas had obstructed both the cystic and the common hepatic ducts; the gall bladder contained yellow bile while the common bile duct contained white bile.

In the only instance where the apparently normal gall bladder was available for histological examination (case 4) it was found to have a normal epithelium but plasma cells and lymphocytes had infiltrated the muscle and submucosa. Four of the five specimens cultured were sterile and free of cells and organisms on Gram staining. The other specimen, from case 4, grew Enterobacteriaceae, and Gram staining showed numerous pus cells and Grampositive rods.

In seven of the nine patients with white bile the 
TABLE II

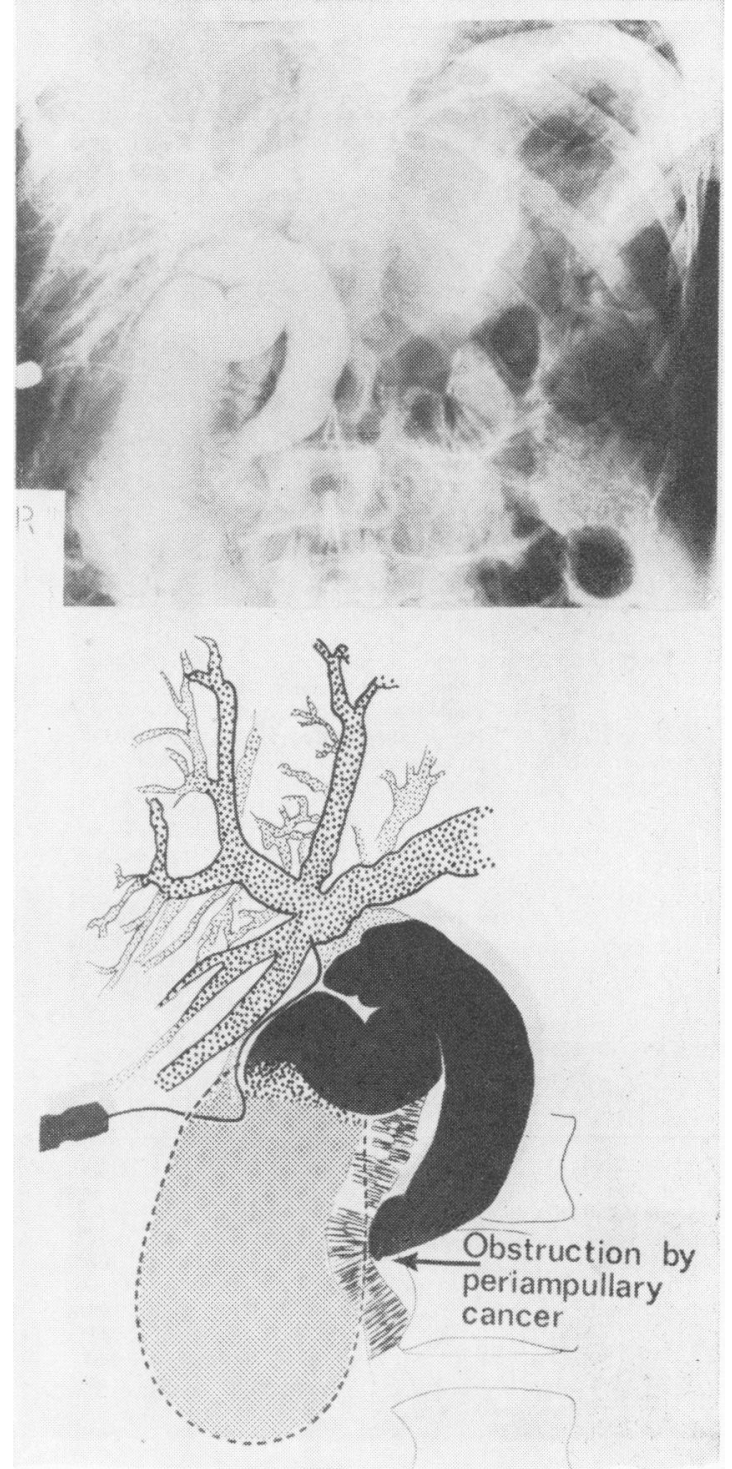

FIG. 1. Transhepatic cholangiogram (case 4). Film taken one and a half hours after instillation of dye. Some dye has passed through the obstruction and entered the duodenum.

level of bilirubin in the serum had fallen by more than $50 \%$ of the preoperative level by the twelfth postoperative day (Table III). One of the two exceptions was a patient with a transhepatic tube splinting the stricture of the common hepatic duct which probably provided inadequate decompression.

\section{DISCUSSION}

In a general way the biochemistry of the white bile
POSTOPERATIVE BILIRUBIN LEVELS IN PATIENTS WITH WHITE BILE

\begin{tabular}{llll} 
Case No. & $\begin{array}{l}\text { Duration of } \\
\text { Obstruction } \\
(w k)\end{array}$ & $\begin{array}{l}\text { Preoperative } \\
\text { Serum Bilirubin } \\
(m g / 100 \mathrm{ml})\end{array}$ & $\begin{array}{l}\text { Postoperative } \\
\text { Period when } \\
\text { Preoperative Serum } \\
\text { Bilirubin } \\
\text { Fell by More than } \\
50 \% \%^{1}(\text { days })\end{array}$ \\
\hline 1 & & & $3-8$ \\
2 & 4 & $24 \cdot 0$ & $0-5$ \\
3 & 4 & $16 \cdot 4$ & $0-11$ \\
4 & 6 & $11 \cdot 9$ & $8-12$ \\
5 & 6 & $13 \cdot 0$ & $4-8$ \\
6 & 4 & $17 \cdot 8$ & $0-5$ \\
7 & 4 & $27 \cdot 0$ & $9-30$ \\
8 & 5 & $35 \cdot 4$ & $13-20$ \\
9 & 5 & $19 \cdot 0$ & $6-11$
\end{tabular}

${ }^{1}$ The first number in each period refers to the day when the bilirubin concentration was more than $50 \%$ of the preoperative level. The second number refers to the postoperative day when the bilirubin level had fallen by more than $50 \%$ of the preoperative level.

in our series resembled that found by others (Griffiths et al, 1963; Bouchier and Cooperband, 1965).

The reason why some patients with obstruction to the extrahepatic biliary tree develop white bile is unknown. Many years ago Rous and McMaster (1921) noted that bile became thick and pale when the bile and the bile ducts were infected. Aronsohn (1935), after studying the formation of white bile in rabbits and dogs, concluded that prolonged biliary infection was always responsible for the production of white bile. This does not apply to man; our results and those of others (Edington and McCallum, 1930; Bouchier and Cooperband, 1965) show that white bile can be sterile.

Rous and McMaster (1921), on the basis of animal experiments, suggested that white bile is formed only when the gall bladder is either not in the obstructed system or when it is so changed pathologisally that its concentrating ability has been lost. Judd and Lyons (1923), after reviewing the histories of 19 patients with white bile, reached a similar conclusion. Yet four of our patients had distal obstruction and their gall bladders were normal except for mild swelling of the wall, and in three of them adequate decompression of the biliary tree was carried out by joining the bowel to the gall bladder. This demonstrates that obstructions distal to a normal gall bladder can result in the formation of white bile and that the distended gall bladder can be used to decompress the biliary tree.

Each of our patients survived the immediate postoperative period and in no instance was death directly attributable to the operation. We believe that the finding of white bile alone should not be taken as a signal to limit the scope of the operation.

The level of bilirubin in the serum fell after 
operation usually at a rate exceeding the average rate suggested by Rundle, Perry, Cass, and Oddie (1958) for the relief of ordinary obstructive jaundice. Their calculations, based on observations made on 17 patients with obstruction of the common bile duct treated with tube drainage of the duct, suggested that if relief of the biliary obstruction was adequate the serum bilirubin level should be halved by an average of $17 \cdot 4$ days after the operation. We suspect that the fall is steeper and that the half value is reached sooner in patients with internal drainage. Certainly in seven of the eight patients with white bile treated by adequate internal drainage the preoperative bilirubin fell by more than $50 \%$ by the twelfth postoperative day (Table III). Presumably in patients with white bile the ability of the liver to excrete bilirubin is not greatly impaired, the serum bilirubin falling more rapidly than it does in patients with ordinary obstructive jaundice treated by external biliary drainage.

\section{SUMMARY}

Observations were made in nine patients who were operated on for obstructive jaundice and who were found to have white bile in the biliary tree. The fluid was free of bilirubin and bile salts and the major cation composition resembled that found in serum. White bile is not necessarily infected bile. White bile can be found in both benign and malignant forms of jaundice; the gall bladder, although it may share in general dilatation of the biliary tree, may be used for decompression. White bile alone does not point to a grave immediate prognosis; an opera- tion appropriate to the patient's general condition and to the nature of the obstruction should be considered. When white bile is found the function of the liver as measured by its ability to clear bilirubin after operation is not greatly impaired.

\section{REFERENCES}

Abell, L. L., Levy, B. B., Brodie, B. B., and Kendall, F. E. (1952). A simplified method for the estimation of total cholesterol in serum and demonstration of its specificity. J. Biol. Chem., $195,357-366$.

Aronsohn, H. G. (1935). Pathogenesis of 'white bile'. Proc. Soc. exp. Biol. (N.Y.), 32, 695-697.

- (1936). Pathogenesis of white bile. Arch. Surg., 32, 1055-1079.

Bouchier, I. A. D., and Cooperband, S. R. (1965). The characteristics of 'white bile'. Gastroenterology, 49, 354-359.

Cameron, G. R., and Oakley, C. L. (1932). Ligation of the common bile duct. J. Path. Bact., 35, 769-798.

Edington, G. H., and McCallum, G. (1930). The occurrence of 'white bile' in gall-stone obstruction: note of a case. Glasg. med. J., 114, 257-264.

Flint, E. R. (1937). Obstructions of the common bile duct. Brit. med. J., 2, 253-256.

Griffiths, D. B., Haber, M. H., Rees, K. R., and Smith, J. F.(1963). Analysis of white bile in a case of cholangiocarcinoma of the hepatic ducts. J. Path. Bact., 85, 389-393.

Haber, M. H., and Rees, K. R. (1963). The production and composition of white bile in the rat. Ibid., 85, 127-137.

Hawthorne, H. R., and Sterling, J. A. (1955). White bile in the common bile duct. Amer. J. Surg., 90, 397-401.

Judd, E. S., and Lyons, J. H. (1923). White bile in the common duct. Ann. Surg., 77, 281-292.

Lake, N. C. (1934). White bile. Lancet, 2, 753-755.

Malloy, H. T., and Evelyn, K. A. (1937) The determination of bilirubin with the photoelectric colorimeter. J. biol. Chem., 119, 481-490.

McMaster, P. D., Broun, G. O., and Rous, P. (1923). Studies on the total bile. III. On the bile changes caused by a pressure obstacle to secretion, and on hydrohepatosis. J. exp. Med., 37, 685-698.

Rous, P., and McMaster, P. D. (1921). Physiological causes for the varied character of stasis bile. J. exp. Med., 34, 75-95.

Rundle, F. F., Perry, D., Cass, M., and Oddie, T. H. (1958). Rise in serum bilirubin with biliary obstruction and its decline curve after operative relief. Surgery, 43, 555-562. Varley, H. (1962). Practical Clinical Biochemistry 3rd ed. W. Heine-
mann, London. 